\title{
The History of Moscow Vysokopetrovsky Stauropegial Monastery and its Role in the Cultural and Religious Life of Moscow in the Early XX Century
}

\author{
Kirill A. Soloviev* \\ Moscow State University of Civil Engineering \\ 26 Yaroslavskoye Shosse, Moscow, 129337, Russia
}

Received 17.12.2016, received in revised form 10.01.2017, accepted 30.01.2017

The main issue of this article is the history of Moscow Vysokopetrovsky Monastery and its role in the cultural and religious life of Moscow in the early XX century. The article is an adaptation of the author's report at the 2012 Christmas matinee. It refers to different points of view on the time when the monastery was founded. The author's attention is generally focused on the history and architecture of the ensemble of the monastery, as well as the monastery's tragic fate in the post-revolutionary years.

Keywords: Vysokopetrovsky Monastery, Renaissance, Aleviz the New, Institute of Theology, exegetical heritage.

DOI: 10.17516/1997-1370-0021.

Research area: history.

\section{Historical Sciences and Archaeology}

At the dawn of the Russian state its capital city, Moscow, was surrounded by watchmonasteries. However, the history of the monastery, in ancient times known as "Petrovsky monastery on Vysokaya", is still insufficiently studied. Some historians believe the founder of the monastery to be the Grand Moscow Prince Dmitry Donskoy; others think that it was the Great Prince Ioann Kalita. Yet, the monastery was most probably founded by the Moscow Metropolitan Peter who was born in Volyn'. His mother Eupraxia had several visions about her son's future before his birth already. At the age of 12 the future metropolitan went into convent and later founded a new monastery on the river Rata. The monastery was named Rata Novodvorsky Monastery. It was a place that the Great Prince Yury L'vovich Galitsko-Volynsky, the Great Prince Daniila Romanovich Galitsky's grandson, often visited. He liked to talk to its hegumen Peter. In 1296 the hegumen Peter met with Maximus, the Metropolitan of Kiev and all Russia. In 1305 after the Metropolitan Maximus's death, the Constantinople Patriarch Athanasius assigned the Rata Novodvorsky Monastery hegumen Peter to be the Metropolitan of Galicia

(C) Siberian Federal University. All rights reserved

* Corresponding author E-mail address: solovyev.cyril@yandex.ru 
and all Russia and later raised him to the rank of Metropolitan of Kiev and all Russia. In 1309 the new Metropolitan of Kiev finally left Kiev and organized his own chair in Vladimir-onKliaz'ma. The new Metropolitan often rode all over his new church lands and started his visits to Moscow, the capital city of a small principality in those days. His relationships with the Great Prince Mikhail of Tver' were not good. At the same time in Moscow he received honor and respect from the Moscow Prince Ioann Danilovich, later known as Kalita (Istoriia Vysokopetrovskogo monastyria, http://www.prokimen.ru). In 1316 it was the metropolitan podvorye (a storehouse with an inn) that was built in the Moscow Kremlin especially for the Metropolitan Peter. However, the Kremlin lacked the required conditions for the metropolitan's private prayer. So, he founded a small monastery in the suburb near the little village Vysokoe on the bank of the Neglinnaya River, close to the forest. The hegumen Ioann was the first builder and hegumen of the monastery, "the founder of a cenobitic monastery in Moscow" (Soikin, 1990). According to a church legend, the Great Prince Ioann Kalita had an alleged vision of high mountains covered with snow while hunting. But on his approach to the mountain the snow melted and later the mountain disappeared. Upon his return to Moscow an overwhelmed Prince told the Metropolitan about that vision. St. Peter interpreted the vision the following way: a mountain is the Prince of Moscow, whereas the snow is the Metropolitan Peter himself; the fact that the snow melted earlier than the mountain disappeared means that the Metropolitan's death will be prior to the Prince's. This legend can be regarded as an approximate mark of the date of the founding of the monastery within the $1318-1326$ period. The main cathedral of a new monastery was initially consecrated in honor of the Holy Apostles Peter and Paul and, consequently, named Petropavlovsky. The Metropolitan Peter died in
Moscow on the $21^{\text {st }}$ of December 1326 (the Old Style) and was buried in the Uspensky Sobor (The Assumption Cathedral) of the Moscow Kremlin. It's an interesting fact that it was in 1327 already when the Metropolitan Peter was canonized by the Russian Orthodox Church. The miracles near his coffin in the Uspensky Sobor were so great that this event became unprecedented in the life of the church. The Metropolitan Peter became the first Russian saint who was canonized just six months after his death and the first Moscow saint in the history.

After the Metropolitan's death the Prince Ioann Kalita took care for the Peter and Paul monastery. It was during his reign when the wooden monastery, damaged by the fire, was restored and given the name of St. Peter, the Metropolitan of Moscow. The monastery became known as Petrovsky monastery (Monastery of St. Peter) from that time (Istoriia Vysokopetrovskogo monastyria, http://www.prokimen.ru). Yet, the monastery was first mentioned in the Great Prince Dmitry Donskoy's charter in 1377. This document runs that Ioann Kalita, the Prince Dmitry Donskoy's grandfather, built a new wooden church in honor of St. Peter. The old decrepit wooden cells and the hegumen's building were rebuilt in 1377-1380. Besides, the Great Prince laid the foundation for another wooden monastery in honor of the Bogolyubskaya icon of the Mother of God, the fact due to which the monastery was called the Bogolyubsky monastery for a time. However, the greatest rise and scope of construction work in the monastery are associated with the names of two Russian Tsars: the Great Prince Vasily III and the Emperor Peter I.

In 1504 Aleviz Fryazin (or Aleviz the New), an Italian architect of the Renaissance period, came to Moscow from Bakhchisarai. Many modern historians of architecture believe that it was the name of a Venetian architect Aleviso Lamberti de Montagnano who was invited to 
Russia by the ambassadors Ralev and Karacharov in 1499 and was well known in Moscow. It was the Crimea Khan Mengly-Ghirey who called him the "New" only once in his letter to the Great Prince Ioann III. There are no more cases when Aleviz Fryazin is mentioned as the "New" in chronicles (Pamiatniki diplomaticheskikh..., 1884).

The khan most likely wanted to emphasize by this nickname that this man was out of all relations to Aloizo de Carezano (Aleviz the Old), a Milanese architect, who completed the construction work of the Kremlin fortification, built the Great Prince's Palace and the walls from the palace to Borovitskaya Tower of the Kremlin within the period from 1494 to 1499. When Aleviz Fryazin arrived in Moscow he was given an honorary responsibility to build the Archangel Cathedral in the Moscow Kremlin. According to the existing evidence, it was Aleviz Fryazin who advised Grigory Borisov, an outstanding Russian architect, on the construction of the Uspensky Cathedral in Dmitrov. In 1514 the Great Prince Vasily III ordered to start the construction of 11 churches, "and it was Aleviz Fryazin who was a master for all those churches" (Polnoe sobranie Russkikh letopisei). In the 60-s of the XX century the historians confirmed that Aleviz was the one who designed the Cathedral of St. Peter, the Metropolitan of Moscow, in Vysokopetrovsky monastery (Beliaev, 1994).

In the course of 1514-1517 years Aleviz Fryazin erected the Cathedral of St. Peter, the Metropolitan of Moscow, in Vysokopetrovsky monastery which is considered the most interesting cathedral among the churches of Moscow, the Great Prince being its sponsor.

"This cathedral is quite rare and unique by its form and spatial planning decision. The cathedral was built in the form of a column and it is centric by its form. It is 23 meters high and built in red brick. It is one-storeyed and twotiered. The first tier is an octagon with its four

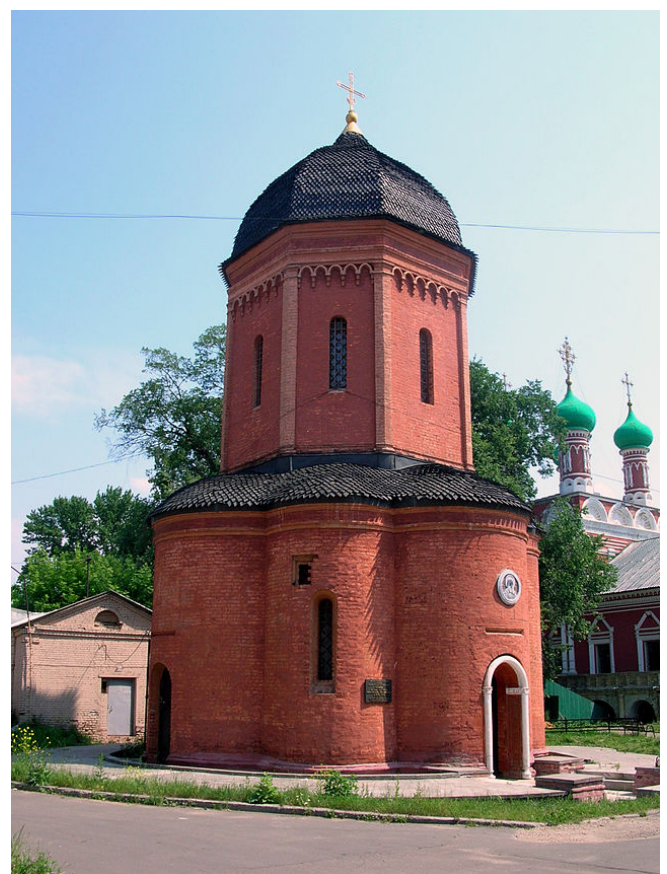

Fig. 1. Moscow Vysokopetrovsky Monastery, the Cathedral of St. Peter, the Metropolitan of Moscow

large semicircles, each facing all the cardinal points. A vosmyerik (an octagonal structure in the old Russian architecture), covered by a helmet-shaped tiled roof, towered over it. The cathedral was surrounded by a circular gallery on the vaultless arches, low stairs of white stone led to the doors" (Istoriia Vysokopetrovskogo monastyria. Sobor Petra Mitropolita). It has long been considered to be the oldest cathedral, existing nowadays, that was erected in the end of the XVII century at the blessing of which Tsar Peter Alekseevich was present. However, B.P. Dedushenko, a soviet architect who carried out field observations during the restoration works in 1979, proved that the present-day cathedral is an ancient cathedral of the beginning of the XV century. B.P. Dedushenko supposed "that a new brick cathedral was built on the site of an original wooden cathedral" (Dedushenko, 1964). This fact that the cathedral was restored and reconsecrated with Peter the Great's participation in 1689-1690 became the cause of such a mistake. 
According to a historian P.M. Stroev's report, a white stone church-porch gallery was built around the cathedral at the same time. During the Great Prince Vasily III's reign a wooden cathedral was built in the monastery in honor of the Intercession of the Theotokos.

The monastery was called Vysoko-Petrovsky in the beginning of the $\mathrm{XV}$ century. The archimandrite's monastery was established there (Soikin, 1910). Yet, it is the end of the XVII century that became the golden age of the monastery. Owing to the future Tsar Peter Alekseevich's birth on the 30th of May 1672 (the Old Style), Kirill Poluektovich Naryshkin, his grandfather, presented him his country house adjoining the monastery's south wall. The tsar presented this land to the monastery and that twice increased its territory. In May, 1682, Ioann and Afanasy Narischkins, two Queen Natalia Kirillovna Naryschkina's brothers, were killed during the first Streltsy uprising. They were initially buried in the wooden Pokrovsky (Intercession) temple. In 1683 with Natalia Kirillovna Naryschkina's sponsorship the Vysokopetrovsky Monastery started the construction of Bogolyubsky Cathedral, one of the monastery's most beautiful cathedrals.

At first the cathedral was believed to be built within the period from 1690 to 1691 . However, after the events of 1682, when the Naryschkin brothers were killed by the Streltsy who were incited by the Miloslavskys, the construction work was symbolically associated with a cruel murder of the Prince Andrey Bogolyubsky in the night from the $28^{\text {th }}$ to $29^{\text {th }}$ of June, 1175. So it is no accidental that the Bogolyubskaya icon of the Mother of God was brought to Moscow from Bogolyubovo (Istoriia Vysokopetrovskogo monastyria, http: //www.plucer.livejournal.com).

It was brought to Vysokopetrovsky monastery. It was decided to erect a new cathedral in honor of this icon. No doubt that the cathedral was also built in memory of the wooden Bogolyubskaya church that existed in the Prince Donskoy's time. The Bogolyubsky Cathedral was planned to be the monastery's main cathedral and also the Naryshkins' burial-vault cathedral. The boyar Kirill Poluektovich Naryschkin, the Tsar

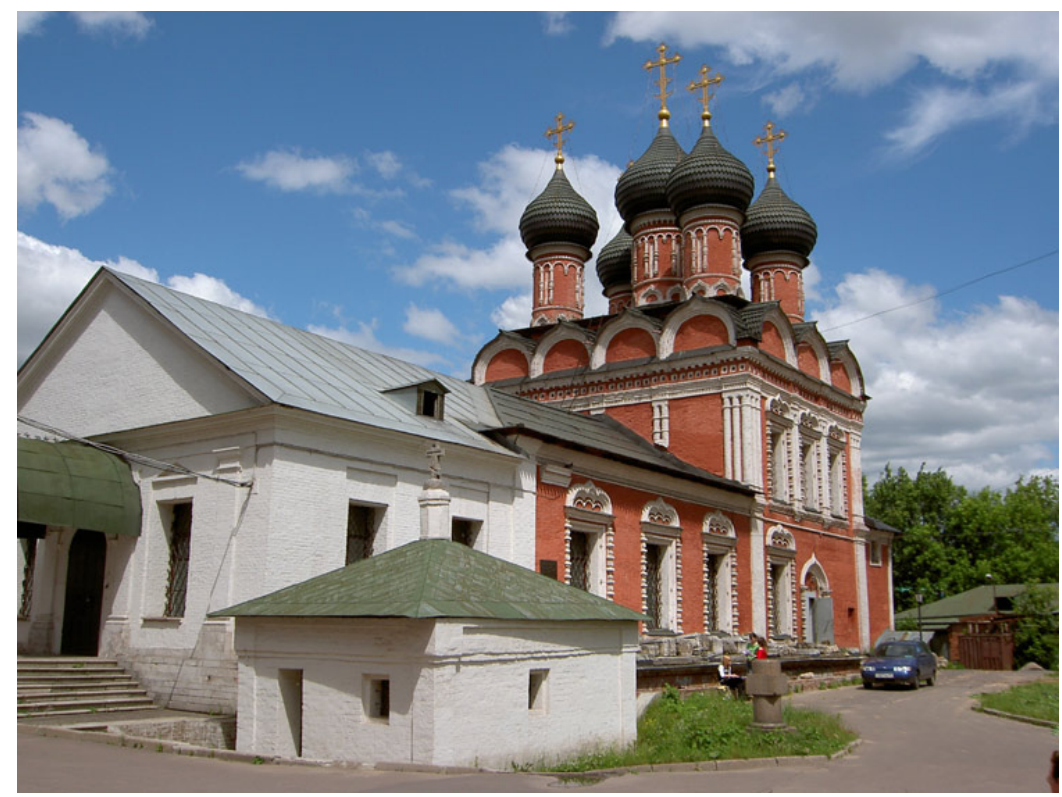

Fig. 2. The cathedral of the Bogolyubskaya Icon of the Mother of God in Vysokopetrovsky Monastery 
Peter the Great's grandfather, was also buried in this cathedral. In the autumn of 1684 it was roofed with wood and consecrated by Patriarch Joachim in the presence of the Tsarina Natalia Kirillovna. The finishing work was carried out for two more years.

Klim Mikhailov, an engraver, made an iconostasis in 1687. Mikhail Miliutin, a disciple of Simon Ushakov, Spiridon Grigor'ev, Fiodor Evtikhiev and Tikhon Ivanov, created the icons in the icon-painting workshops of the Arsenal within the period from 1687 to 1688 . 54 icons were made there. In the XX century this iconostasis was completely destroyed after the cathedral was closed in 1929. According to Soslanbek Tavasiev, a well-known Soviet sculptor, in 1929 the icons were broken out of the iconostasis and burned in the monastery's courtyard. A great consecration of Bogolyubsky Cathedral took place only in 1690. A unique list of the Bogolyubskaya Icon of the Mother of God, presented by Tsar Peter Alekseevich, was kept in the cathedral. This cathedral is very well preserved. In the course of 1960-1980 the cathedral was completely renovated and restored by the architect B.P Dedushenko.

In 1689, by Tsar Peter Alekseevich's order they started the construction of a new refectory cathedral of St. Sergius of Radonezh in Vysokopetrovsky monastery in memory of the tsar's escape from the princess Sophia Alekseevna's plot. Two side- chapels of St. Alexis, the Metropolitan of Moscow, and St. Mitrophan Voronezhsky were consecrated in the refectory cathedral. The public gallery on arcades connects the refectory cathedral with the cells building. The works were completed in 1689-1692. The tsar gave a new present to the monastery during the consecration of St. Sergius Cathedral in 1696, the present being the Vlakhernskaya icon of the Mother of God. In the course of 1690-1696 a majestic bell tower over the gate with the temple over the gate in honor of the Intercession of the Theotokos was also erected.

During the restoration of the bell tower in the 90 s s of the XX century the interior decoration (icons, chandeliers, lamps and crosses) was made in ceramics by G.V. Kupriianov, an artist; an altar barrier was made by Iu. Alonov and B. Osipov, the architects. The temple over the gate was re-consecrated on the $14^{\text {th }}$ of October 1996, Pokrov feast day. In 1744 the lady-in-waiting N.A. Naryshkina financed the construction of the Tolgsk Icon of the Mother of God church, designed by the architect I.F. Michurin, the Tolgsk Icon of the Mother of God being her investment to the monastery (Vysokopetrovskii muzhskoi monastyr').

In the years of 1750-1755 the over the gate cathedral of St. Pakhomy the Great was erected over the southern monastery gate. It was designed by the Prince D.M. Ukhtomsky's architect (Denisov, 1908).

It is interesting that in 1914, after a centenary interruption in liturgies that was caused by a cruel plunder of the monastery by the French in 1812, the cathedral was re-consecrated as Petropavlovsky Cathedral. In the end of the XVIII century on the right side of Bogolyubsky Cathedral a burial vault chapel of the Naryshkins family was erected.

Finally in 1905 in the south passageway of the monastery's Holy Gate they built a chapel of a sacred image of the Kazanskaya Icon of the Mother of God that was deeply respected. The akathist the Mother of God was prayed there up to 1928 . In 2001, a throne of the Kazanskaya Icon of the Mother of God was arranged in the chapel. In 1690 , a special temple for monastic services was built in the monastery's fraternal house. Like a fraternal house, this temple is connected with the refectory church of St. Sergius of Radonezh by the open gallery. 
In 1812 the monastery was seriously damaged by the invasion of the French, who plundered Vysokopetrovsky monastery. There are some evidences that "according to the order of Marshal Mortier, the French Governor of Moscow, the French shot the arsonists, captured on the territory of Vysokopetrovsky monastery, and buried them here, near the Holy Gate (Istoriia Vysokopetrovskogo monastyria, http://www. allReferat.org.ua).

In the early XX century the name of the Sergiev Posad bishop Bartholomew (Remov) is associated with Vysokopetrovsky Monastery. In the 20-s of the XX century he was in close relations with the Metropolitan Sergii (Stragorodsky).

Nikolai Fedorovich Remov was born in Moscow on the $3^{\text {rd }}$ of October, 1888. He became a monk in 1911. In 1912 he was raised to the rank of celibate priest. In 1914 he completed his education in the Moscow Theological Academy. In 1920 His Holiness Patriarch Tikhon appointed him the Head of the Institute of Theology. On the $28^{\text {th }}$ of February, 1921 he was released from Butyrskaya prison for health reasons. He was imprisoned because of his strong opposition to the opening of the relics of St. Sergius of Radonezh in 1920. In July 28, 1921 the celibate priest Bartholomew was raised to the rank of Bishop of Sergiev Posad, vicar of the Moscow diocese. In 1923-1929 he was the superior of Vysokopetrovsky monastery. According to his numerous disciples' evidences, and the evidence of Nun Ignatia (Petrovskaya) in particular, Bishop Bartholomew was beloved by people for his passionate service and austerity. Nun Ignatia (Petrovskaya) believed that Bishop Bartholomew had a gift of providence. In Moscow of the 20-s Bishop Bartholomew had a reputation of a saint old man. He was considered an organizer of several Moscow monastic secret societies. Staying within the jurisdiction of the Patriarchal Locum Tenens Metropolitan Sergii (Stragorodsky), Bartholomew did not support his

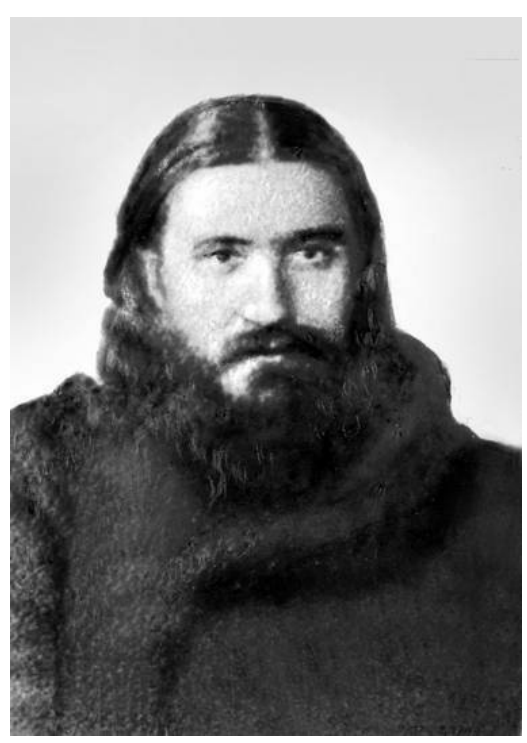

Fig. 3. Bartholomew Bishop (N.F. Remov)

policy. In the end of the 20-s of the XX century he opened the secret Moscow Theological Academy of Vysokopetrovsky Monastery. In 1928 he was arrested by the OGPU and agreed to cooperate with the Soviet authorities. Bishop Bartholomew most likely hoped that he would be able to keep secret monasticism in Moscow by doing this (Varfolomei (Remov)).

People, who knew him, noted that the bishop did not give the state security agencies the details that they counted on. However, the end of Bishop Bartholomew's life was tragic. Hoping that the rapprochement between the Catholic and the Orthodox Churches could help stop the persecution of the Christians in the Soviet Union, he began showing his sympathy with the Catholic Church (Pravoslavnaia entsyklopedia).

On the $9^{\text {th }}$ of June, 1934 he was raised to the rank of archbishop. He was arrested on the $21^{\text {th }}$ of February, 1935 and on the $26^{\text {th }}$ of June, 1935 he was shot. In the early 90 -s of the XX century the idolators of his memory collected the documents about his possible canonization as a new martyr. They believed that Bishop Bartholomew's accusations in secret Catholicism are groundless. 
Bishop Bartholomew's correspondence with the Catholic bishop Neves and bishop Michel d'Erbini is kept in the Vatican archives (the Fund of the General Archive of the AugustinianAssumptsionists).

These documents are widely known by the Orthodox as well as Catholic researchers (Lesourd, 1976). His Grace left an interesting exegetical heritage. In particular, his works dedicated to the Prophet Avvakum are widely known (The Book of the Prophet Avvakum. Introduction to Interpretation. Sergiev Posad, 1913. The Prophet of Faith (1914), In Theological Journal).

In 1929, Vysokopetrovsky Monastery was finally closed and its territory was sequentially occupied by communal apartments and various state agencies. This caused the destruction of the monastery buildings and cluttering of its territory. In 1959, the territory of the monastery was handed over to the Ministry of Culture of the USSR. Thus, the State Literary Museum was located there and is still there. The refectory church housed the folk dance ensemble "Berezka" till 1992. Since 1991 the superior's house of the monastery has been housing the Synodal Department of Religious Education and Catechesis. In 1992 the refectory church of St. Sergius of Radonezh was opened for liturgies. In 1993 Vysokopetrovsky Monastery received the status of the Patriarch's monastery. In 2009 the Right Reverend Mercury, Bishop of Zaraisk, was appointed a superior of the monastery, and in October 10-11, 2009, the decision of the monastic life revival in the monastery was approved at a meeting of the Holy Synod. The current governor-superior of the monastery is Abbot Peter (Eremeev), the rector of the Russian Orthodox University of St. Apostle and Evangelist Ioann the Theologian.

It seems that in contemporary Moscow a newfound monastery may become a place of particular reverence for St. Peter, the first Metropolitan of Moscow. The memory of him

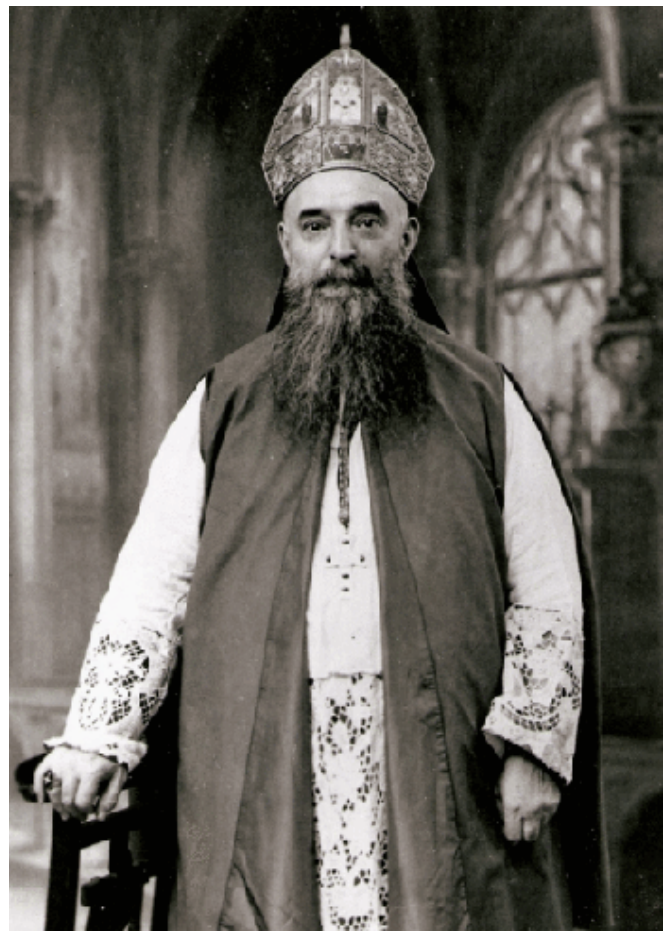

Fig. 4. Michel-Joseph Bourguignon d'Herbigny (May 8, 1880 (Lille) - December 24, 1957 (Aix-enProvence)), Catholic bishop, the Head and participant of the Russian Apostolate in foreign countries, church diplomat

was never forgotten by Orthodox Christians. Since the Monastery of St. Peter had long been in desolation, this memory was as if hidden away. It is no secret that many Russian contemporaries do not know about the Metropolitan Peter and his deeds for a small city of Moscow in the beginning of the XIV century. Meanwhile this Great Metropolitan as if spiritually foresaw the future greatness of Moscow among other cities. $\mathrm{He}$ actually relocated his metropolitan throne to Moscow. This action had a great affect on strengthening of the status of Moscow as a spiritual center of the Russian lands. There are also hopes that a memorial to the Russian people shot on the territory of the monastery by the French during the occupation of 1812 can be built in the monastery. Incidentally, there is no deserved monument to the heroes of the Moscow resistance in the 1812 War in Moscow so far. 


\section{References}

Beliaev, L.A. (1994). Drevnie monasteri Moskvy (kontsa XIII - nachala XIV vekov) po dannym arkheologii [Ancient Monasteries of Moscow in the End of the XII Century - the Beginning of the XIV Century as per archeological data). Moscow, $160 \mathrm{p}$.

Dedushenko, B. (1964). K istorii ansamblia moskovskogo Vysoko-Petrovskogo monastyria [On the history of Moscow Vysokopetrovsky Monastery Ensemble]. Drevnerusskoe iskusstvo [Ancient Russian Art]. Moscow, 257 p.

Denisov, L.I. (1908). Pravoslavnye monastyri Rossiiskoi Imperii [Orthodox Monasteries of the Russian Empire]. Moscow.

Istoriia Vysokopetrovskogo monastyria [The History of Vysokopetrovsky Monastery]. Available at: http://www.prokimen.ru (accessed December 2011)

Istoriia Vysokopetrovskogo monastyria [The History of Vysokopetrovsky Monastery]. Available at: http //www.plucer.livejournal.com (accessed December 2011)

Istoriia Vysokopetrovskogo monastyria [The History of Vysokopetrovsky Monastery]. Available at: http://www.allReferat.org.ua (accessed December 2011)

Istoriia Vysokopetrovskogo monastyria. Sobor Petra Mitropolita [The history of Vysokopetrovsky Monastery, The Cathedral of St. Peter, the metropolitan of Moscow]. Iz semeinogo arkhiva [From the Family Archive]. Available at: http://www.plucer.livejournal.com (accessed December 2011)

Lesourd, P. (1976). Entre Pome ET Moscou. Le jesuite clandestin. Mgr. Michel d'Erbigny. Paris.

Pamiatniki diplomaticheskikh snoshenii drevnei Rusi s derzhavami inostrannymi [The Monuments of Russian Diplomatic Relation with Foreign Countries]. (1884). Vol. 1. St.-Petersburg, 551-552.

Polnoe sobranie Russkikh letopisei [The Complete Collection of Russian Chronicles]. 254-255.

Pravoslavnaia entsyklopedia [The Orthodox Encyclopedia]. (2003). 716-717.

Soikin, P.P. (1910). Pravoslavnye Russkie Obiteli [The Russian Orthodox Monasteries]. St.Petersburg, $712 \mathrm{p}$.

Varfolomei (Remov) [Bartholomey (Remov)]. Available at: http://www.wikipedia.org (accessed December 2011)

Vysokopetrovskii muzhskoi monastyr' [Vysokopetrovsky monastery]. Available at: http://www. russian-chruch.ru (accessed December 2011) 


\title{
История Московского Высоко-Петровского \\ ставропигиального мужского монастыря \\ и его роль в культурной и религиозной \\ жизни Москвы в начале XX века
}

\author{
К.А. Соловьев \\ Московский государственный \\ строительный университет \\ Россия, 129337, Москва, Ярославское шоссе, 26
}

В статье идет речь об истории Московского Высоко-Петровского монастыря и о его роли в культурной и религиозной жизни Москвы начала ХХ столетия. Статья является адаптированным вариантом доклада автора на Рождественских чтениях 2012 года. В статье говорится о разных точках зрения на время основания монастыря. Основное внимание автор уделяет истории развития и архитектуре монастырского ансамбля, а также о трагической судьбе обителей в послереволюиионные годы.

Ключевые слова: Высоко-Петровский монастырь, Эпоха Возрождения, Алевиз Новый, Высший Богословский институт, экзегетическое наследие.

Научная специальность: 07.00.00 - исторические науки. 